288 Reports \& Proceedings-Pakeontographical Society.

II.-Paleontographical Soctety.

Annual General Meeting.

April 25, 1919.-Dr. Henry Woodward, F.R.S, President, in the Chair:

The Council presented its seventy-second annual report and announced the completion of the seventy-first volume of monographs, comprising instalments of Wealden and Purbeck Fishes, Pliocene Mollusca, Cambrian Trilobites, and Palæozoic Asterozoa. It referred to the increased cost of publication, and the consequent reduction in the size of the annual volume. It also appealed to members to help in making the work of the Society more widely known so that the number of subscribers might be increased. The officers were re-elected, and Messrs. H. Dewey, F. L. Kitchin, W. P. D. Stebbing, and $H$. Woods were elected new members of Council.

OBITUARY.

\title{
CAPTAIN T. E. G. BAILEY, B.A., F.G.S.
}

Captain T. E. G. Bailey, B.A., F.G.S., was killed in action on April 2, 1919, while serving in North Russia. Bailey will long be remembered for his share in "The Geology of Nrassalard" published in the Quarterly Journal of the Geological Society, 1910. The paper in question was written in conjunction with Mr. A. R. Andrew, and gives the geological results of a mineral survey carried out for the Imperial Institute during the years 1906-8. Since then Bailey did much good work as an oil-geologist in Burma and Borneo until the outbreak of war. He came home from Borneo to take a temporary commission in the Yorkshire Regiment, and with them he served in France during the years 1915-18. $\mathrm{He}$ was promoted for his services during the Battle of the Somme, 1916, and was severely wounded in the Battle of Arras, 1917. In November, 1918, he was sent to Russia.

\section{FERNAND PRIEM. \\ BORN NOVEM̈Ber 10, 1857. DIED APRIL 4, 1919.}

Proprssor Frenand Priem was one of the most successful students of fossil fishes and made many important contributions to our knowledge. He was born at Bergues, near Dunkerque, and after graduating in the University of Paris he studied palæontology under the late Professor Albert Gaudry. He became honorary Professor of Geology in the Lyceum of Henry IV and correspondent of the National Museum of Natural History, Paris. For many years most of his energies were devoted to research, and his numerous writings on fossil fishes are as valuable for their bearing on stratigraphical geology as on ichthyology. Besides papers published by the Geological Society of France, he wrote a memoir on the fossil fishes of the Paris Basin for the Annales de Paléontologie (1908) and a report on the Cretaceous fishes collected by the De Morgan Mission in Persia.

A. S. W. 